\title{
Typhoon Eye Effect vs. Ripple Effect: The Role of Family Size on the Mental Health under the COVID-19 Pandemic in Pakistan
}

\author{
Tooba Lateef ${ }^{1}$, Jiyao Chen ${ }^{2}$, Muhammad Tahir ${ }^{3}$, Teba Abdul Lateef ${ }^{4}$, Bryan Chen ${ }^{5}$, \\ Jizhen $\mathrm{Li}^{6}$, Stephen X. Zhang ${ }^{7}$ *
}

1. Assistant Professor, Department of Biochemistry, University of Karachi, Main University Road, Karachi-75270, Sindh, Pakistan Karachi, Sindh, Pakistan

2. Associate Professor, Oregon State University, 416 Austin Hall Corvallis OR USA

3. Associate Professor, Sir Syed University of Engineering and Technology, ST-16, University Road, Block-5, Gulshan-e-Iqbal, Karachi-75300, Sindh, Pakistan

4. Lecturer, Department of Nutrition and Dietetics, Ra'ana Liaquat Ali Khan Government College of Home Economics, Karachi, MPhil Researcher, Department of Food Science and Technology, University of Karachi, Main University Road, Karachi-75270, Sindh, Pakistan

${ }^{5 .}$ Crescent Valley High School, 4444 NW Highland Dr, Corvallis, OR 97330, USA

6. Professor, Tsinghua University, 258A Weilun Building, Beijing, China

7. Associate Professor, University of Adelaide, Australia; Address: 9-28 Nexus10 Tower, 10 Pulteney St, Adelaide SA 5000, Australia

\section{*Correspondence:}

Corresponding Author

stephen.x.zhang@gmail.com 
medRxiv preprint doi: https://doi.org/10.1101/2020.11.19.20229856; this version posted November 22,2020 . The copyright holder for this preprint (which was not certified by peer review) is the author/funder, who has granted medRxiv a license to display the preprint in

It is made available under a CC-BY-NC-ND 4.0 International license .

\section{Abstract}

Background: The recent outbreak of COVID-19 impacts the mental health of people worldwide. The mental conditions and the associated predictors of adults in Pakistan, the fifth most populous country in the world, during the COVID-19 remains understudied. We aim to investigate distress, anxiety and overall mental health and their associated predictors among Pakistani adults in this pandemic. We specifically examine the mental health issues based on the distance to the epicenter, a predictor that has revealed opposing evidence in other countries based on the theories of typhoon eye effect and ripple effect. The samples consist of 601 adults who were surveyed online about 2.5 months into the outbreak across Pakistan with varying distance to the epicenter of COVID-19 of Karachi in Pakistan.

Results: The results showed that $9.2 \%$ and $19.0 \%$ of the participants surpassed the cut-off of distress and anxiety disorders, respectively. Overall, the distance to the epicenter positively predicted the mental health of adults in Pakistan, and family size negatively moderated this effect. The distance to the epicenter negatively predicted distress and anxiety disorders for adults in large families, which are quite common in Pakistan.

Conclusion: The evidence of the study interestingly finds the prediction of the mental health of people by their distance to the epicenter depends on the family. The evidence of this study can help to provide the initial indicator for mental health care providers to screen vulnerable groups in Pakistan, a populous country that continues to struggle to cope with the COVID-19 pandemic.

Keywords: COVID-19, Pakistan, Typhoon eye effect, Ripple effect, Family size, Mental health 
medRxiv preprint doi: https://doi.org/10.1101/2020.11.19.20229856; this version posted November 22,2020 . The copyright holder for this preprint (which was not certified by peer review) is the author/funder, who has granted medRxiv a license to display the preprint in It is made available under a CC-BY-NC-ND 4.0 International license.

\section{INTRODUCTION}

In Pakistan, the first case of COVID-19 appeared on February 26, 2020 in Karachi, the largest city and the financial, industrial, and trading hub of the country. The initial cases were imported to Karachi from abroad but later on community spread started, and Karachi became the initial epicenter of the virus infection in Pakistan [1]. As COVID-19 spreads, a psychological panic among the public happened across the country, as it has happened in other countries as well such as China, Iran, Italy, Peru, Bolivia, etc. [2-8]. For instance, one study of students has shown moderate anxiety and distress as pandemic affects daily life activities in Pakistan [9].

While it seems that people closer to the center of any disastrous event would be affected more and in turn might have more mental issues [10] and the effect of catastrophic event declines for people with greater geographical distance to the epicenter, known as the "ripple effect" [11]. However, findings have demonstrated an opposite effect referred to as "psychological typhoon eye effect". In the 2008 Wenchuan earthquake, it was first observed that people closer to the area of crisis felt calmer [12]. Later on the same phenomenon was observed during different public health emergencies [13-15], and also in the epidemic of Severe Acute Respiratory Syndrome (SARS) [10].

In the ongoing COVID-19 pandemic, the opposite theories of psychological typhoon eye effect and ripple effect have been reported [3, 16-19]. The survey findings of China and Brazil documented that people far from the epicenter had worse anxiety and distress [18-20]. Though a survey in China on healthcare staff including nurses indicated ripple effect [21]. 
medRxiv preprint doi: https://doi.org/10.1101/2020.11.19.20229856; this version posted November 22,2020 . The copyright holder for this preprint (which was not certified by peer review) is the author/funder, who has granted medRxiv a license to display the preprint in It is made available under a CC-BY-NC-ND 4.0 International license .

Few other studies also reported psychological disturbances in several countries but the association with geographical distance was not assessed and hence limited the explanation of both theories $[5,22]$. Up till now there has been no research conducted in the general population of Pakistan to assess anxiety and distress.

Therefore, the present study aims to study the impact of COVID-19 on the two opposite theories of typhoon eye effect and ripple effect in Pakistan. Moreover, this study is the first to examine the typhoon eye effect and ripple effect on people living with varying sizes of family, because people tend to live with larger families in Pakistani culture, and the larger family may either drain or provide buffering resource to mental issues. This study will also be one of the first of its kind to the mental health among adults in varying geographical locations in Pakistan. The findings of the research can help to pinpoints useful predictors that will help to provide targeted mental health support in vulnerable groups during the COVID-19 pandemic that still goes on in Pakistan.

\section{METHODS}

\section{Study Context}

The first case of COVID-19 in Pakistan was reported on February 26, 2020 in Karachi [23]. The largest city of Pakistan and the capital of Sindh, with a population of 16 million [24] has the high burden of disease as compared to other cities [1]. At the time of the study, Feb 26 to May 11 2020, there were 9480 cases in Karachi, representing 41.5\% of the 22,820 total active cases in the entire country [23]. Hence Karachi was a clear epicenter in Pakistan at the time of the study. 
medRxiv preprint doi: https://doi.org/10.1101/2020.11.19.20229856; this version posted November 22,2020 . The copyright holder for this preprint (which was not certified by peer review) is the author/funder, who has granted medRxiv a license to display the preprint in

It is made available under a CC-BY-NC-ND 4.0 International license .

\section{Data collection and sample}

About 2.5 months into the outbreak, on May $4^{\text {th }}-11^{\text {th }} 2020$, we conducted an online survey of adults from all over Pakistan. On May $4^{\text {th }}, 2020$, when the survey started, the total number of confirmed cases of COVID-19 reached 21,501, and the death toll reached to 486 in Pakistan [23].

The study was approved by the Institutional Bioethical Committee of the University of Karachi (IBC KU -143/2020). The participants, after their consent, filled the online survey voluntarily. The survey promised the participants the confidentiality and anonymity of their responses. The participants could answer the survey in Urdu (the back-translated version) or English (the version developed originally).

\section{Variables}

The participants reported their demographic characteristics such as age, gender, education, and marital status. They also reported their family size and daily exercise hours in the past week. We computed the distance from their geographical locations to Karachi, the COVID-19 epicenter of Pakistan.

The outcome variables included distress, anxiety, and, mental health. Distress was measured by K6, the six-item Kessler mental distress scale $(0=$ never, $4=$ almost all of the time, $\alpha=0.83$ ) with the cut-off point of 13 [25]. Anxiety was measured by the Generalized Anxiety Disorder-7 scale (GAD-7) $(0=$ never, rarely, $3=$ always; $\alpha=0.88)$ with the cut-off point of 10 [26]. Mental health was assessed by Short Form-12 (SF-12) [27-29]. SF12 cover 8 sub-scales including physical functioning, physical role, body pain, general health, 
medRxiv preprint doi: https://doi.org/10.1101/2020.11.19.20229856; this version posted November 22,2020 . The copyright holder for this preprint (which was not certified by peer review) is the author/funder, who has granted medRxiv a license to display the preprint in It is made available under a CC-BY-NC-ND 4.0 International license .

functionality, social functioning, emotional role, and mental health.

\section{Data analysis approach}

We used Stata 16.0 to summarize the variables and to predict distress and anxiety by logistic regression and to predict mental health by ordinary least squares regression with a $95 \%$ confidence level.

\section{RESULTS}

\section{Descriptive findings}

The results showed that $47.6 \%$ of the 601 working adults were female, and $62.4 \%$ were younger than 29 years old, $26.0 \%$ were between 30 to 39 years, and $11.6 \%$ were 40 years or older. $67.7 \%$ of participants were single, $30.8 \%$ married, and $1.5 \%$ divorced. Most of the participants (70.5) had an undergraduate degree or higher with few participants (29.0) had a high school diploma (intermediate). On average, they exercised 0.77 hours each day with an SD of 0.79 hours. Overall, they had a family size of 6 with SD of 3 and resided 0.27 thousand kilometers away from Karachi, Sindh with SD of 0.51 thousand kilometers (see Table 1).

\section{Descriptive and comparative findings on the outcome variables}

About one-tenth of participants surpassed the cut-off of distress (9.2\%) and about one-fifth of participants surpassed that of anxiety (19.0\%). By comparing our findings with those in 11 studies using similar measurements, we found that overall the mental health conditions of Pakistani adults were comparable or less than those in several samples in China, Spain, and Italy with one exception (see Table 2 for a summary). Anxiety disorder in our sample was 
medRxiv preprint doi: https://doi.org/10.1101/2020.11.19.20229856; this version posted November 22,2020 . The copyright holder for this preprint (which was not certified by peer review) is the author/funder, who has granted medRxiv a license to display the preprint in It is made available under a CC-BY-NC-ND 4.0 International license .

higher than that in a sample of adults in China in late Feb 2020 [30].

\section{Predictors of distress, anxiety, and mental health}

The distance to the epicenter of COVID-19 in Pakistan negatively predicted the mental health of adults, but the relationship depended on their family size (b=-0.71; $95 \%$ CI: -1.04 to -0.38 ; $\mathrm{P}=0.000$ ). Margin analysis showed that the distance to the epicenter positively predicted mental health for adults in a small family (e.g. at a single family: $b=2.79$; $95 \%$ CI: 0.28 to 5.30; $\mathrm{P}=0.039$ ). In contrast, the distance to the epicenter negatively predicted mental health for adults in large family (e.g. at an 8-member family: $b=-2.19 ; 95 \%$ CI: -3.85 to -0.54 ; $\mathrm{P}=0.009$ ). Similarly, the relationship of the distance to the epicenter and mental health disorders of adults also depended on their family size (OR=1.25; 95\% CI: 1.04 to 1.49 ; $\mathrm{P}=0.017$ for distress, and $\mathrm{OR}=1.14 ; 95 \% \mathrm{CI}: 1.03$ to $1.26 ; \mathrm{P}=0.015$ for anxiety). Margin analysis showed that the distance to the epicenter positively predicted distress disorder for adults in large families (e.g. at an 8-member family: OR=0.065; 95\% CI: 0.032 to 0.098 ; $\mathrm{P}=0.000$ ) and anxiety disorder (e.g. at an 8-member family: OR=0.066; $95 \%$ CI: 0.008 to 0.12; $\mathrm{P}=0.026$ ) (see Figure 1).

In addition, adults who exercised more have better mental health $(b=1.28 ; 95 \%$ CI: 0.31 to $2.25 ; \mathrm{P}=0.010)$ and less likely to experience distress disorders $(\mathrm{OR}=0.66 ; 95 \% \mathrm{CI}: 0.45$ to 0.96; $\mathrm{P}=0.028$ ). The results also suggest that older the person, the improved mental health $(\mathrm{b}=0.28 ; 95 \%$ CI: 0.06 to $0.40 ; \mathrm{P}=0.007)$.

\section{DISCUSSION}

Pandemics have a myriad impact on the mental health of people [31]. In the recent outbreak 
medRxiv preprint doi: https://doi.org/10.1101/2020.11.19.20229856; this version posted November 22,2020 . The copyright holder for this preprint (which was not certified by peer review) is the author/funder, who has granted medRxiv a license to display the preprint in It is made available under a CC-BY-NC-ND 4.0 International license .

of COVID-19, it has been reported that COVID-19 itself with many other factors has increased mental issues in various countries [4, 8, 32-34]. To the best of our knowledge this is the first study to examine the psychological typhoon eye effect or ripple effect from the epicenter among Pakistani adults. The findings of psychological distress and anxiety scales revealed the prevalence of moderate distress and anxiety in our sample. Compared to other recently published studies, the results showed that the rate of anxiety and distress among Pakistani adults was greater as compared to those in China [30], whereas lower as compared to Italy, Spain and United States $[6,35,36]$. These differences might be due to less number of reported cases and deaths as compared to the countries that have high distress and anxiety. With regard to the variables associated with distress, anxiety and mental health in Pakistan, family size and exercise were worth noting predictors found in our sample. Previous literature revealed that geographical distance from the epicenter as an important prognosticator during catastrophic events [19]. In the present study the findings overall showed that participants residing distantly from the epicenter have better mental health with less distress and anxiety, supporting the ripple effect rather than the typhoon eye effect [7, 17]. However, the association can diverge based on individuals' family size. The mental disorder decreased by the distance to the epicenter for individuals in small families, indicating the typhoon eye effect. By contrast, mental disorder increased by the distance to the epicenter for individuals in larger families, showing the ripple effect.

Our results on the ripple effect vs. typhoon eye effect, together with other studies on the same topic in China, Brazil, and Peru [7, 17, 20], suggest the prediction of these two opposing theories may differ based on the countries studied. Such differences are 
medRxiv preprint doi: https://doi.org/10.1101/2020.11.19.20229856; this version posted November 22,2020 . The copyright holder for this preprint (which was not certified by peer review) is the author/funder, who has granted medRxiv a license to display the preprint in It is made available under a CC-BY-NC-ND 4.0 International license .

understandable, as countries vary in their geography, media and social media reporting, medical systems, cultures, the availability of personal protective equipment (PPE), labor and employment conditions, the policies of lockdown, the ease of working from home, and maintaining a living in a pandemic, and the information in both mainstream and social media, etc. [5]. The results therefore suggest we need to identify the predictive effect of the ripple effect vs. typhoon eye effect as a predictive model of mental health in individual countries during the Covid-19 pandemic. Our results suggest such studies can focus on identifying relevant contingency factors in individual countries. In Pakistan, we focused on family size, and the possible explanation for family size to reverse the effect of the ripple effect vs. typhoon eye effect might be due to socio-economic burden on the families due to lockdown in the country. As studies have shown that financial constraints or economic hardships not only increased behavioral problems but also damaged the physical and mental health status of individuals and their families [37]. Thus, our findings identify family size as a critical contingency factor in the prediction of typhoon eye effect and ripple effect. Future research can focus on identifying unique contingency factors in the country of the study.

As in previous studies in Brazil, China and Iran [4, 5, 20], our sample also identified exercise hours as one of the predictors of distress, anxiety and mental health during COVID-19. The results showed that participants who put in more hours for physical activity in terms of daily exercise in their routine, had better mental health and were less likely to develop distress and anxiety symptoms. Many studies have reported that performing daily exercise might have an impact on anxiety and distress symptoms [38, 39]. Due to the sedentary life style in COVID-19 pandemic, it has been observed that people gave less 
medRxiv preprint doi: https://doi.org/10.1101/2020.11.19.20229856; this version posted November 22,2020 . The copyright holder for this preprint (which was not certified by peer review) is the author/funder, who has granted medRxiv a license to display the preprint in It is made available under a CC-BY-NC-ND 4.0 International license .

attention to their physical health than in normal circumstances [40]. Thus, particularly in this pandemic era when people were extra stressed, adding physical activity in the daily routine can play a role in reducing distress and anxiety. In comparisons with the recent studies of Iran, China and Brazil [41-43], age also predicted mental health in the Pakistani population. The results showed that older people had better mental health, which might be due to the joint family system in Pakistan. It has been reported that traditional family systems, such as those in South Asia, can contribute to healthier mental states among older people as compared to those living in smaller nuclear family systems [44]. The positive attitude from a lack of information about COVID-19 could also be another factor for better mental health of older people [45]. As compared to older people, younger people rely more on social media and the internet that have helped to spread negative information on the pandemic $[18,30]$.

The overall findings of the present study can help to identify the vulnerable individuals in Pakistan during this crisis of COVID-19. Exercise, family size, age and distance to the epicenter are the key predictors of distress, anxiety and mental health in Pakistan during this pandemic. More specifically the relationship of the geographical distance to the epicenter with distress, anxiety and mental health represented the ripple effect in large families. However, the relationship varied depending on family size and showed the typhoon eye effect in small families. Thus, results suggest psychiatrists and mental health care providers that the geographical distance to epicenter, with an important contingency of facility size, can play a major role in screening of people with high risk.

This study had some limitations. During the survey dates, the total active cases of 
medRxiv preprint doi: https://doi.org/10.1101/2020.11.19.20229856; this version posted November 22, 2020. The copyright holder for this preprint (which was not certified by peer review) is the author/funder, who has granted medRxiv a license to display the preprint in It is made available under a CC-BY-NC-ND 4.0 International license.

COVID-19 in Pakistan had yet to reach its peak, and the situation continues to evolve. In addition, as the study was conducted through an online questionnaire, selective participation and coverage area error might be present. While we aimed for broad coverage of the adults in various parts of Pakistan, we do not claim our sample to be representative of the adults' population in Pakistan.

\section{CONCLUSION}

In conclusion the present study uncovered the prevalence of distress and anxiety disorders in Pakistani adults during COVID-19. The results indicate that geographical distance is a crucial factor in screening vulnerable groups and suggest future studies to examine the use of the typhoon eye effect or ripple effect in terms of identifying mentally vulnerable people with a focus to identify the relevant contingency factors.

\section{DECLARATIONS}

\section{Ethics Approval and Consent to Participate}

The study was approved by Institutional Bioethical Committee, University of Karachi (approval no. IBC KU-143/2020). Each study participant filled the online questionnaire voluntarily after their consent.

\section{Consent for Publication}

Not applicable

\section{Availability of Data and Materials}


medRxiv preprint doi: https://doi.org/10.1101/2020.11.19.20229856; this version posted November 22, 2020. The copyright holder for this preprint (which was not certified by peer review) is the author/funder, who has granted medRxiv a license to display the preprint in It is made available under a CC-BY-NC-ND 4.0 International license.

The datasets presented in this article are not available. Requests to access the datasets should be directed to corresponding author.

\section{Competing Interest}

The authors declare that there are no potential conflicts of interest with respect to the research, authorship, and/or publication of this article.

\section{Funding}

None

\section{Authors Contribution}

T. L.: Investigation (data collection), Writing - Original, Writing - Review \& Editing

J. C.: Investigation, Formal analysis, Investigation, Writing - Original, Writing - Review \& Editing, Validation

M. T.: Investigation (data collection), Resources, Writing - Review \& Editing

T. A. L.: Investigation (data collection), Writing - Review \& Editing

B. C.: Visualization; Writing - Review \& Editing

J. L.:

S. X. Z.: Conceptualization, Investigation, Methodology, Formal analysis, Writing - Original,

Writing - Review \& Editing, Supervision

All authors read and approved the final manuscript.

\section{Acknowledgements}


medRxiv preprint doi: https://doi.org/10.1101/2020.11.19.20229856; this version posted November 22,2020 . The copyright holder for this preprint (which was not certified by peer review) is the author/funder, who has granted medRxiv a license to display the preprint in It is made available under a CC-BY-NC-ND 4.0 International license .

We thank the Institutional Bioethical Committee, the University of Karachi for support. We also thank all individuals who have devoted their time to participate in this study.

\section{REFERENCES}

1. Ilyas N, Azuine RE, Tamiz A. COVID-19 pandemic in Pakistan. Int J Transl Med Res Public Health. 2020;4(1):37-49. doi: 10.21106/ijtmrph.139.

2. Kang L, Ma S, Chen M, Yang J, Wang Y, Li R, et al. Impact on mental health and perceptions of psychological care among medical and nursing staff in Wuhan during the 2019 novel coronavirus disease outbreak: A cross-sectional study. Brain, Behav Immun. 2020;87(2020):11-17. doi: 10.1016/j.bbi.2020.03.028.

3. Zhang Y, Cao X, Wang P, Wang G, Lei G, Shou Z, et al. Emotional "inflection point" in public health emergencies with the 2019 new coronavirus pneumonia (NCP) in China. J Affect Disord. 2020;276(2020):797-803. doi: 10.1016/j.jad.2020.07.097.

4. Zhang S X, Wang Y, Rauch A, Wei F. Unprecedented disruption of lives and work: Health, distress and life satisfaction of working adults in China one month into the COVID-19 outbreak. Psychiatry Res. 2020;2020(288):112958. doi: 10.1016/j.psychres.2020.112958.

5. Jahanshahi AA, Dinani MM, Li J, Zhang SX. The distress of Iranian adults during the Covid-19 pandemic - More distressed than the Chinese and with different predictors. Brain, Behav Immun. 2020;87(2020):124-125. doi: 10.1016/j.bbi.2020.04.081.

6. Moccia L, Janiri D, Pepe M, Dattoli L, Molinaro M, Martin VD, et al. Affective temperament, attachment style, and the psychological impact of the COVID-19 outbreak: an early report on the Italian general population. Brain, Behav Immun. 2020;87(2020):75-79. doi: 10.1016/j.bbi.2020.04.048. 
medRxiv preprint doi: https://doi.org/10.1101/2020.11.19.20229856; this version posted November 22,2020 . The copyright holder for this preprint (which was not certified by peer review) is the author/funder, who has granted medRxiv a license to display the preprint in It is made available under a CC-BY-NC-ND 4.0 International license .

7. Yáñez JA, Jahanshahi AA, Alvarez-Risco A, Li J, Zhang SX. Anxiety, Distress, and Turnover Intention of Healthcare Workers in Peru by Their Distance to the Epicenter during the COVID-19 Crisis. Am J Trop Med Hyg. 2020;00(0):1-7. doi: 10.4269/ajtmh.20-0800.

8. Zhang SX, Sun S, Jahanshahi AA, Alvarez-Risco A, Ibarra VG, Li J, et al. Developing and testing a measure of COVID-19 organizational support of healthcare workers - results from Peru, Ecuador, and Bolivia. Psychiatry Res. 2020;291(2020):113174. doi: 10.1016/j.psychres.2020.113174.

9. Salman M, Asif N, Mustafa ZU, Khan TM, Shehzadi N, Hussain K, et al. Psychological impact of COVID-19 on Pakistani university students and how they are coping. medRxiv. 2020; doi: 10.1101/2020.05.21.20108647.

10. Xie XF, Stone E, Zheng R, Zhang RG. The 'Typhoon Eye Effect': determinants of distress during the SARS epidemic. J Risk Res. 2011;14(9):1091-1107. doi: 10.1080/13669877.2011.571790.

11. Slovic P. Perception of risk. Science. 1987;236(4799):280-285. doi: 10.1126/science. 3563507 .

12. Li S, Rao LL, Bai XW, Zheng R, Ren XP, Li JZ, et al. Progression of the "Psychological typhoon eye" and variations since the Wenchuan earthquake. PLoS ONE. 2010;5(3):e9727. doi: 10.1371/journal.pone.0009727.

13. Hoven CW, Duarte CS, Lucas CP, Wu P, Mandell DJ, Goodwin RD, et al. Psychopathology among New York City public school children 6 months after September 11. Arch Gen Psychiatry. 2005;62(5):545-552. doi: 10.1001/archpsyc.62.5.545. 
medRxiv preprint doi: https://doi.org/10.1101/2020.11.19.20229856; this version posted November 22,2020 . The copyright holder for this preprint (which was not certified by peer review) is the author/funder, who has granted medRxiv a license to display the preprint in It is made available under a CC-BY-NC-ND 4.0 International license .

14. Maderthaner R, Guttmann G, Swaton E, Otway HJ. Effect of distance upon risk perception. J Appl Psychol. 1978;63(3):380-382. doi: 10.1037/0021-9010.63.3.380.

15. Zheng R, Rao LL, Zheng XL, Cai C, Wei ZH, Xuan YH, et al. The more involved in lead-zinc mining risk the less frightened: A psychological typhoon eye perspective. J Environ Psychol. 2015;44(2015):126e134. doi: 10.1016/j.jenvp.2015.10.002.

16. Fangfang W, Shuhan MA, Hanxue Y, Yue Q, Bin Z. Psychological "typhoon eye effect" and "ripple effect": Double perspective test of risk perception and anxiety characteristics of people in different COVID-19 severity regions. Acta Psychol Sin. 2020;52(9):1087-1104. doi: 10.3724/SP.J.1041.2020.01087.

17. Zhang SX, Huang H, Wei F. Geographical distance to the epicenter of Covid-19 predicts the burnout of the working population: Ripple effect or typhoon eye effect? Psychiatry Res. 2020;288(2020):112998. doi: 10.1016/j.psychres.2020.112998.

18. Tang PM, Zhang SX, Li CH, Wei F. Geographical identification of the vulnerable groups during COVID-19 crisis: The typhoon eye effect and its boundary conditions. Psychiat Clin Neuros. 2020;doi:10.1111/pcn.13114.

19. Zhang L, Ma M, Li D, Xin Z. The psychological typhoon eye effect during the COVID-19 outbreak in China: The role of coping efficacy and perceived threat. Global Health. 2020;16:105. doi.org/10.1186/s12992-020-00626-8.

20. Zhang SX, Wang Y, Jahanshahi AA, Li J, Schmitt VGH. Mental distress of adults in Brazil during the COVID-19 crisis. medRxiv. 2020;doi: 10.1101/2020.04.18.20070896.

21. Huang L, Lei W, Xu F, Liu H, Yu L. Emotional responses and coping strategies in nurses and nursing students during Covid-19 outbreak: A comparative study. PLoS ONE. 
medRxiv preprint doi: https://doi.org/10.1101/2020.11.19.20229856; this version posted November 22,2020 . The copyright holder for this preprint (which was not certified by peer review) is the author/funder, who has granted medRxiv a license to display the preprint in It is made available under a CC-BY-NC-ND 4.0 International license .

2020;15(8):e0237303. doi: 10.1371/journal.pone.0237303.

22. Zhang Y, Ma ZF. Impact of the COVID-19 pandemic on mental health and quality of life among local residents in Liaoning province, China: A cross-sectional study. Int J Env Res Pub He. 2020;17:2381. doi: 10.3390/ijerph17072381.

23. Official updates coronavirus; COVID-19 in Pakistan. http://covid.gov.pk/stats/pakistan. (Accessed on June 02, 2020).

24. World population review; Karachi population 2020 (Demographics, Maps, Graphs). https://worldpopulationreview.com/world-cities/karachi-population. (Accessed on June 02, 2020).

25. Kessler RC, Andrews G, Colpe LJ, Hiripi E, Mroczek DK, Normand SLT, et al.. Short screening scales to monitor population prevalences and trends in non-specific psychological distress. Psychol Med. 2002;32(6):959-976. doi: $10.1017 / \mathrm{s} 0033291702006074$.

26. Kroenke K, Spitzer RL, Williams JBW, Löwe B. An ultra-brief screening scale for anxiety and depression: The PHQ-4. Psychosomatics. 2009;50(6):613-21. doi: 10.1176/appi.psy.50.6.613.

27. Ware JJr, Kosinski M, Keller SD. A 12-Item short-form health survey: construction of scales and preliminary tests of reliability and validity. Med Care. 1996;34(3):220-233. doi: 10.1097/00005650-199603000-00003.

28. Naseem K, Khurshid S, Khan SF, Moeen A, Farooq MU, Sheikh S, et al. Health related quality of life in pregnant women: A comparison between urban and rural populations. $\mathrm{J}$ 
medRxiv preprint doi: https://doi.org/10.1101/2020.11.19.20229856; this version posted November 22,2020 . The copyright holder for this preprint (which was not certified by peer review) is the author/funder, who has granted medRxiv a license to display the preprint in It is made available under a CC-BY-NC-ND 4.0 International license .

Pak Med Assoc. 2011;61(3):308-12.

29. Jenkinson C, Chandola T, Coulter A, Bruster S. An assessment of the construct validity of the SF-12 summary scores across ethnic groups. Journal of Public Health Med. 2001;23(3):187-194. doi: 10.1093/pubmed/23.3.187.

30. Song K, Xu R, Stratton TD, Kavcic V, Luo D, Hou F, et al. Sex differences and psychological stress: Responses to the COVID-19 epidemic in China. Res Square. 2020;doi: 10.1101/2020.04.29.20084061.

31. Pappas G, Kiriaze IJ, Giannakis P, Falagas ME. Psychosocial consequences of infectious diseases. $\quad$ Clin $\quad$ Microbiol Infect. 2009;15(8):743-747. doi: 10.1111/j.1469-0691.2009.02947.x.

32. Dai H, Zhang SX, Looi KH, Su R, Li J. Perception of health conditions and test availability as predictors of adults' mental health during the COVID-19 pandemic: A survey study of adults in Malaysia. Int J Env Res Pub He. 2020;17:5498. doi: 10.3390/ijerph17155498.

33. Ahmad A, Rahman I, Agarwal M. Early psychosocial predictors of mental health among Indians during coronavirus disease 2019 outbreak. J Health Sci. 2020;X(X):1-10. doi: 10.17532/jhsci.2020.950.

34. Zhang J, Lu H, Zeng H, Zhang S, Du Q, Jiang T, et al. The differential psychological distress of populations affected by the COVID-19 pandemic. Brain Behav Immun. 2020;87(2020):49-50. doi: 10.1016/j.bbi.2020.04.031.

35. Twenge J, Joiner TE. Mental distress among U.S. adults during the COVID-19 pandemic. 
medRxiv preprint doi: https://doi.org/10.1101/2020.11.19.20229856; this version posted November 22,2020 . The copyright holder for this preprint (which was not certified by peer review) is the author/funder, who has granted medRxiv a license to display the preprint in It is made available under a CC-BY-NC-ND 4.0 International license .

PsyArXiv. 2020;doi:10.31234/osf.io/wc8ud.

36. González-Sanguino C, Ausín B, Castellanos MA, Saiz J, López-Gómez A, Ugidos C, et al. Mental health consequences during the initial stage of the 2020 Coronavirus pandemic (COVID-19) in Spain. Brain Behav Immun. 2020;87(2020):172-176. doi: 10.1016/j.bbi.2020.05.040.

37. Knapp M, Wong G. Economics and mental health: The current scenario. World Psychiatry. 2020;19:3-14.doi: 10.1002/wps.20692.

38. Qureshi S, Riaz H, Awan MM, Khushnood K, Hussain R. Association of depression, physical activity levels and general psychological health among physical therapy students of Rawalpindi and Islamabad. J. Shifa Tameer-e-Millat Uni. 2019;2(1):26-30. doi: 10.32593/jstmu/Vol2.Iss 1.27.

39. Mochcovitch MD, Deslandes AC, Freire RC, Garcia RF, Nardi AE. The effects of regular physical activity on anxiety symptoms in healthy older adults: A systematic review. Braz J Psychiat. 2016;38(3):255-61. 10.1590/1516-4446-2015-1893.

40. Nowak PF, Bozek A, Blukacz M. Physical activity, sedentary behavior and quality of life among university students. Biomed Res. Int. 2019;2019:9791281. doi: $10.1155 / 2019 / 9791281$.

41. Peyman N, Olyani S. Iranian older adult's mental wellbeing during the COVID-19 epidemic. Asian J Psychiatr. 2020;54(2020):102331. doi: 10.1016/j.ajp.2020.102331.

42. Qiu J, Shen B, Zhao M, Wang Z, Xie B, Xu Y. A nationwide survey of psychological distress among Chinese people in the COVID-19 epidemic: implications and policy recommendations. Gen. Psychiatr. 2020;33:e100213. doi: 10.1136/ gpsych-2020-100213. 
medRxiv preprint doi: https://doi.org/10.1101/2020.11.19.20229856; this version posted November 22,2020 . The copyright holder for this preprint (which was not certified by peer review) is the author/funder, who has granted medRxiv a license to display the preprint in It is made available under a CC-BY-NC-ND 4.0 International license .

43. Zhang, SX, Wang Y, Jahanshahi AA, Schmitt VGH. First study on mental distress in Brazil during the COVID-19 crisis. medRxiv. 2020;doi: 10.1101/2020.04.18.20070896.

44. Taqui AM, Itrat A, Qidwai W, Qadri Z. Depression in the elderly: Does family system play a role? A cross-sectional study. BMC Psychiatry. 2007;7:57. doi: $10.1186 / 1471-244 X-7-57$.

45. Jeronimus BF, Snippe E, Emerencia AC, de Jonge P, Bos EH. Acute stress responses after indirect exposure to the MH17 airplane crash. Br. J. Psychol. 2019;110(4):790-813. doi: 10.1111/bjop. 12358.

46. Wang H, Xia Q, Xiong Z, Li Z, Xiang W, Yuan Y, et al. The psychological distress and coping styles in the early stages of the 2019 coronavirus disease (COVID-19) epidemic in the general mainland Chinese population: A web-based survey. PLoS ONE. 2020;15(4):e0233410. doi: 10.1371/journal.pone.0233410.

47. Guo Q, Zheng Y, Shi J, Wang J, Li G, Li C, et al. Immediate psychological distress in quarantined patients with COVID-19 and its association with peripheral inflammation: A mixed-method study. Brain, Behav. Immun. 2020;88(2020):17-27. doi: 10.1016/j.bbi.2020.05.038.

48. Gao J, Zheng P, Jia Y, Chen H, Mao Y, Chen S, et al. Mental health problems and social media exposure during COVID-19 outbreak. PLoS ONE. 2020;15(4):e0231924. doi: 10.1371/journal.pone.0231924.

49. Ni MY, Yang L, Leung CMC, Li N, Yao X, Wang Y, et al. Mental health, risk factors, and social media use during the COVID-19 epidemic and cordon sanitaire among the community and health professionals in Wuhan, China: Cross-sectional survey. JMIR 
medRxiv preprint doi: https://doi.org/10.1101/2020.11.19.20229856; this version posted November 22,2020 . The copyright holder for this preprint (which was not certified by peer review) is the author/funder, who has granted medRxiv a license to display the preprint in It is made available under a CC-BY-NC-ND 4.0 International license .

Ment Health. 2020;7(5):e19009. doi: 10.2196/19009.

50. Meng H, Xu Y, Dai J, Zhang Y, Liu B, Yang H. Analyze the psychological impact of COVID-19 among the elderly population in China and make corresponding suggestions.

Psychiatry. Res. 2020;289(6):112983. doi: 10.1016/j.psychres.2020.112983. 
medRxiv preprint doi: https://doi.org/10.1101/2020.11.19.20229856; this version posted November 22, 2020. The copyright holder for this preprint (which was not certified by peer review) is the author/funder, who has granted medRxiv a license to display the preprint in It is made available under a CC-BY-NC-ND 4.0 International license.

Table 1. Predicting working adults' depression, anxiety, and mental health ( $N=601$ )

Variables Logistic regression Linear regression

\begin{tabular}{|c|c|c|c|c|c|c|}
\hline \multirow[t]{2}{*}{ n $(\%)$} & \multicolumn{2}{|c|}{ Distress } & \multicolumn{2}{|c|}{ Anxiety } & \multicolumn{2}{|c|}{ Mental health } \\
\hline & OR $(95 \% \mathrm{CI})$ & $\mathrm{p}$-value & $O R(95 \% \mathrm{CI})$ & $\mathrm{p}$-value & $b(95 \% \mathrm{CI})$ & $\mathrm{p}$-value \\
\hline
\end{tabular}

Gender

$\begin{array}{rccccccc}\text { Male } & 315(52.4) & .74 & .315 & 1.09 & .688 & -.98 & .233 \\ \text { Female } & 286(47.6) & (.42-1.33) & & (.72-1.65) & & (-2.62-.64) & \\ & & & & & & & \\ 18-19 & 30(5.0) & & & & & .23 & \\ 20-29 & 339(57.4) & .97 & .178 & .98 & .421 & (.06-.40) & .007 \\ 30-39 & 156(26.0) & (.92-1.02) & & (.93-1.03) & & & \\ 40-79 & 70(11.6) & & & & & \end{array}$

Marital status

Single $407(67.7)$

Reference-

Married $185(30.8)$

$$
1.09
$$

$(.46-2.59)$

.89

Divorced $9(1.7)$

2.02

\section{Education}

$(.18-22.8)$

$\begin{array}{cccc}.845 & .89 & .722 & -.35 \\ & (.47-1.69) & .72 & (-2.66-1.97) \\ .570 & .69 & & -1.91 \\ & (.08-6.45) & .748 & (-10.70-6.86)\end{array}$
.770 .668

Primary $2(0.3)$

Secondary $1(0.2)$

Intermediate $175(29.0)$

.95
$(.51-1.76)$

.865

$\begin{array}{ccc}1.10 & & -1.96 \\ (.67-1.80) & .698 & (-3.96-.03)\end{array}$

.054

Graduate or
higher $24(70.5)$

Exercise hours per day
Mean[SD]
$0.77[0.79]$
.66
$(.45-.96)$
.028
.81
$(.63-1.05)$
.112
1.28
$(.31-2.25)$
.010
Distance to Karachi (1000 kilometer)
.54
$(.18-1.6)$
.265
$\begin{array}{ccc}.58 & & 3.51 \\ (.27-1.24) & .160 & (.74-6.28)\end{array}$
.013

$$
\text { Mean[S }
$$

\section{Family size}

$$
\begin{array}{rc}
1 & 5(0.8) \\
2 & 17(2.8) \\
3 & 54(9.0) \\
4 & 99(16.5) \\
5 & 134(22.3) \\
6 & 122(20.3) \\
7 & 58(9.7) \\
8 & 41(6.8) \\
9 & 20(3.3) \\
\geq 10 & 51(8.49)
\end{array}
$$$$
.76
$$

Distance * Family size

$$
1.25
$$

.013

$$
\begin{gathered}
.91 \\
(.82-1.00)
\end{gathered}
$$

.052

.19

$(-.13-.50)$

.017

1.14

.015

$-.71$

.000 
Table 2. The comparisons of adults' distress and anxiety issues during the COVID-19 pandemic across studies

\begin{tabular}{|c|c|c|c|c|}
\hline Measure & Sample description; data collection time & Prevalence & Comparison with this study & Source \\
\hline Distress & This study & $9.2 \%$ & - & \\
\hline Kessler-6 & 369 adults in China, Feb 20-21, 2020 & $6.2 \%$ & $\begin{array}{l}-3.0 \%(-6.3 \% \text { to } 0.6 \%) \\
\chi^{2}(1)=2.8, p=0.10\end{array}$ & {$[4]$} \\
\hline Kessler-10 & 500 adults in Italy, April 10-13, 2020 & $18.6 \%$ & $\begin{array}{l}9.4 \%(5.5 \% \text { to } 13.3 \%) \\
\chi^{2}(1)=22.2, \mathrm{p}<0.0001\end{array}$ & {$[6]$} \\
\hline Kessler-6 & 1599 adults in China, Feb 1-4, 2020 & $\begin{array}{l}\text { Mean (SD): } 7.7 \\
( \pm 7.7)\end{array}$ & $\begin{array}{l}2.2 \%(1.49 \%-2.8 \%) \\
\mathrm{T}(2198)=6.4, \mathrm{p}<0.0001\end{array}$ & [46] \\
\hline Kessler-6 & 2032 adults in the U.S., late April 2020 & $27.7 \%$ & $\begin{array}{l}18.5 \%(15.3 \% \text { to } 21.4 \%) \\
\chi^{2}(1)=88.3, \mathrm{p}<0.0001\end{array}$ & [35] \\
\hline Anxiety & This study & $19.0 \%$ & - & \\
\hline GAD-2 & $\begin{array}{l}3088 \text { adults in } 32 \text { provinces of China, Feb 20-27, } \\
2020\end{array}$ & $13.2 \%$ & $\begin{array}{l}-5.83 \%(-2.6 \% \text { to }-9.3 \%) \\
\chi^{2}(1)=13.9, \mathrm{p}=0.0002\end{array}$ & {$[30]$} \\
\hline GAD-2 & 3480 adults in Spain, March 21-27, 2020 & $21.6 \%$ & $\begin{array}{l}2.3 \%(-1.3 \% \text { to } 5.5 \%) \\
\chi^{2}(1)=1.6, \mathrm{p}=0.21\end{array}$ & [36] \\
\hline GAD-7 & 103 adults in China, Feb 10-28, 2020 & $22.3 \%$ & $\begin{array}{l}3.3 \%(-4.4 \% \text { to } 12.7 \%) \\
\chi^{2}(1)=0.6, p=0.44\end{array}$ & [47] \\
\hline GAD-7 & $\begin{array}{l}98 \text { adults in Zhongshan, Guangdong in China, Feb } \\
15-29,2020\end{array}$ & $23.4 \%$ & $\begin{array}{l}4.4 \%(-3.6 \% \text { to } 14.1 \%) \\
\chi^{2}(1)=1.03, \mathrm{p}=0.31\end{array}$ & [34] \\
\hline GAD-7 & 4872 adults in China, Jan 31-Feb 2, 2020 & $22.6 \%$ & $\begin{array}{l}3.6 \%(.1 \%-6.8 \%) \\
\chi^{2}(1)=4.0, \mathrm{p}=.045\end{array}$ & [48] \\
\hline GAD-2 & 1577 adults in Wuhan, China, Feb 18-24, 2020 & $23.8 \%$ & $\begin{array}{l}4.8 \%(.9 \%-8.5 \%) \\
\chi^{2}(1)=5.7, p=.017\end{array}$ & [49] \\
\hline GAD-7 & 1556 seniors older than 60 years in China & $37.1 \%$ & $\begin{array}{l}18.1 \%(14.0 \%-21.9 \%) \\
\chi^{2}(1)=65.2, p<.0001\end{array}$ & {$[50]$} \\
\hline
\end{tabular}


medRxiv preprint doi: https://doi.org/10.1101/2020.11.19.20229856; this version posted November 22,2020 . The copyright holder for this preprint (which was not certified by peer review) is the author/funder, who has granted medRxiv a license to display the preprint in perpetuity.

It is made available under a CC-BY-NC-ND 4.0 International license.

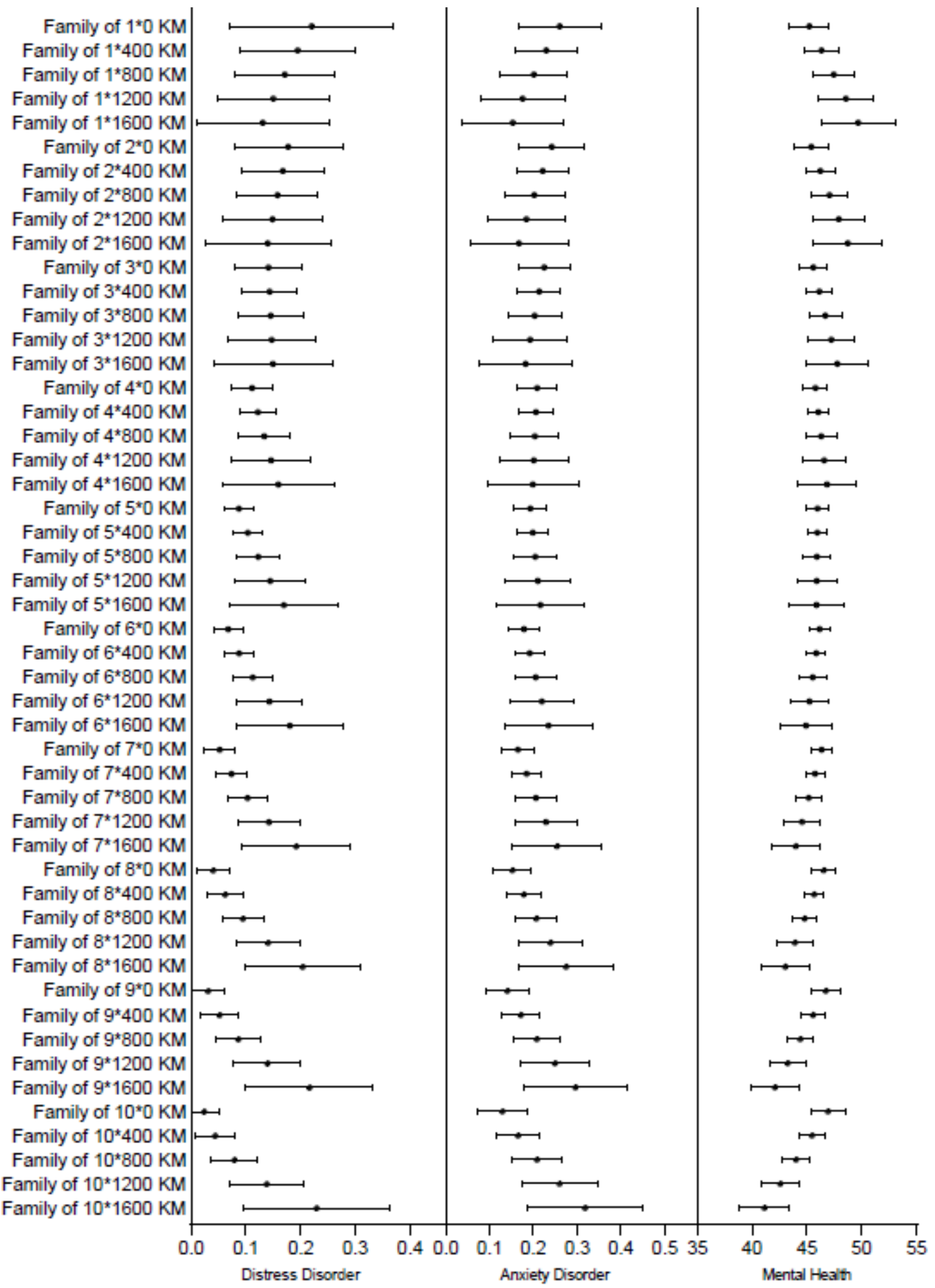

Figure 1. Predicted value and $95 \%$ confidence intervals of distress, anxiety and mental health by family size and distance to the epicenter 